
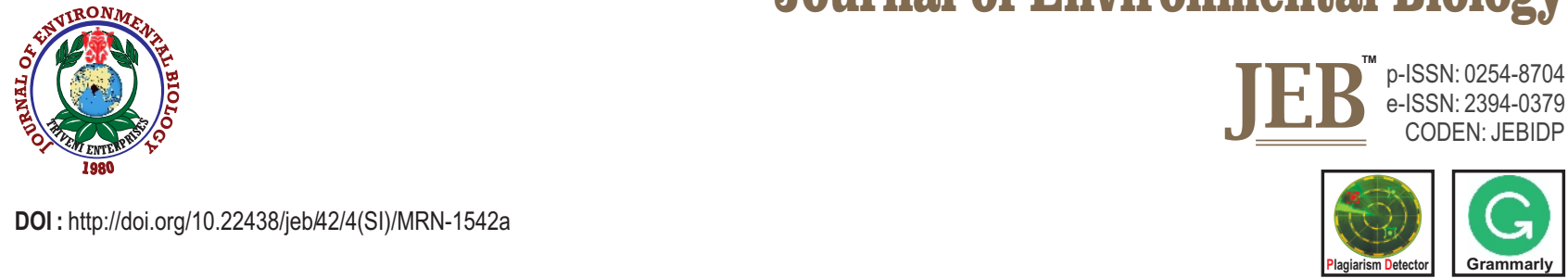

\title{
Host-specific influence on early growth and physiological attributes of sandal (Santalum album) grown in farmlands
}

\author{
A. Balasubramanian, C.N. Hari Prasath*, S. Radhakrishnan and M. Sivaprakash \\ Department of Silviculture \& Natural Resource Management, Forest College and Research Institute, Mettupalayam -641 301, India \\ *Corresponding Author Email : prasathforestry@gmail.com
}

\section{Abstract}

Aim: The present study aimed to investigate the host- specific compatibility of sandal (Santalum album) for better root proliferation and boosting the growth of tree.

Methodology: Sandal (Santalum album) was grown with 8 different leguminous and non-leguminous species at early stage to evaluate its biometric growth (height and basal diameter) and physiological (chlorophyll, photosynthesis rate and transpiration rate) performance under field conditions.

Results: Sandal grown with Sesbania grandiflora recorded highest biometric observations, chlorophyll, photosynthesis and transpiration rate followed by Sandal + Albizia lebbeck and sandal + Casuarina junghuhniana. The sandal grown with leguminous host showed superior growth performance than sandal grown with non-leguminous host.

Interpretation: The present study recommended that Sesbania grandiflora can be grown as transit host for boosting the growth of sandal.

Key words: Hemi-root parasites, Host-specific compatibility, Root proliferation, Sandal

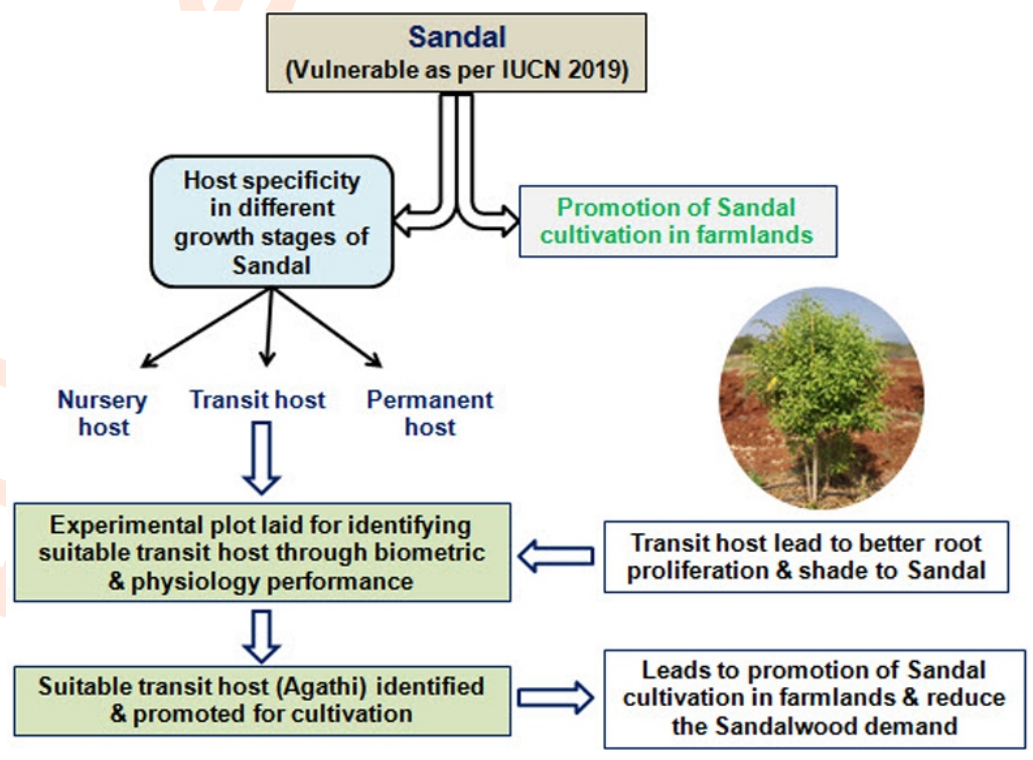

How to cite : Balasubramanian, A., C.N. Hari Prasath, S. Radhakrishnan and M. Sivaprakash: Host-specific influence on early growth and physiological attributes of sandal (Santalum album) grown in farmlands. J. Environ. Biol., 42, 1162-1167 (2021). 


\section{Introduction}

Globally, tropical forests cover merely $7 \%$ of Earth's land surface and harbour more than half of the world's species (Wilson, 1988) which are highly threatened by human activities (Htun et al., 2011). Researchers have predicted that clearing half of the world's residual forests would remove $85 \%$ of all the species inhabited by the people (Pimm and Raven, 2000; Pandey et al., 2018). Data from tropical forest suggested that, continuous loss of more than one higher plant species per day (Myers, 1990), disappearance of 20 ha forests, destruction of more than 1800 population per hour (Hughes et al., 1997) and loss of species population at a percentage rate of 3-8 times than the rate of species extinction due to natural disturbance, biotic disturbance and habitat alterations (Costanza et al., 1997; Kittur et al., 2014; Baboo et al., 2017; Maurya et al., 2019). In India, tropical forest covers about $80.69 \%$ of the total forest land and tropical dry deciduous forest accounts for 41.87 \%of total forest (FSI 2011). These anthropogenic disturbances have lead to land degradation, species replacement and species disappearance from their natural habitat (Bargali et al., 2018; Bargali etal., 2019; Manral etal., 2020).

Parasitism is the concept of deriving some part or all of the water and nutrition from other living trees. In every biome, about 1 per cent of the plants/trees belong to angiosperms with the character of parasitism. The nature of parasitic plants is formation of modified root called haustoria, which penetrate into the host plant and joins the conductive system of xylem, phloem or both. Among different angiosperms tree species, sandal (Santalum album) is a valuable tree species with semi-root parasite nature with root penetration into host plant (Radomiljac et al., 1998, Yang et al., 2014; Marshall et al., 1994). Sandal trees partially rely on the host plant to take up water and nutrient through the functional haustoria eventhough sandal trees have functional chloroplast to perform photosynthesis. Indian sandalwood is superior in world market for its aromatic heartwood and root (Kim et al., 2005), however, due to the illicit felling and smuggling in the past, the sandal population in the country has declined and reached to the vulnerable status (IUCN, 2020). Due to the increasing anthropogenic pressure, the declining population of sandalwood in the country has lead to the production variation of $4000 \mathrm{Mg}$ during 1950 s to $500 \mathrm{Mg}$ in 2007 from. The natural population of sandal in India was recorded mainly in Deccan plateau (Karnataka, Tamil Nadu, Kerala and Andhra Pradesh) on peninsular region (Gairola et al., 2008).

To overcome this scenario, cultivation of sandal in the farmlands have been promoted in the countries like India, Australia, China and Indonesia (Dhanya et al., 2010) through farm forestry, agroforestry, home gardens (Balasubramanian et al., 2018). The poor understanding of parasite-host relationship leads to problematic of both during seed germination, regeneration and establishment of sandal (Surendran et al., 1998). During the life cycle of sandal, total three host are recommended for its better establishment, growth and function. Three hosts, viz., nursery host are planted during germination of sandal seedlings to facilitate the uptake of nutrients through prolific rooting of host (Ehrhart and Fox, 1995); Transit host are planted to bride the stage of field establishment at early stage of growth up to 2 years through interim support for sandal root system, partial shading and also enhanced micro-climate and permanent/ long term host planted after the transit host and the host leads to prolonged support through permanent root association, formation of functional haustorial network and enhance uptake of nutrients. Promotion of sandal with host throughout the life cycle will built up the growth, but, once the host was removed wilting and leaf shedding on sandal tree was recorded (Roche et al., 2014). Still there is unanimity of accepting the hemiparasitic nature of sandal, as host playing a role in supplying water and nutrient to the sandal. Interestingly, many of the research studies have proven the successful establishment of sandal and host plant interaction in nursery and field condition. Considering all these factors, a field level experiment was carried out to identify the host suitability for transit host (Intermediate host) in sandal by studying the growth and physiological parameters.

\section{Materials and Methods}

The study was carried out in one-year-old Sandal plantation established and maintained at Forest College and Research Institute, Mettupalayam, Coimbatore, India. The soil of the Sandal plantation established with the host was Illupanatham soil series, slightly alkaline ( $\mathrm{pH}-7.87)$ in nature; soil was loamy sand, well drained and non saline (EC-0.20 dSm${ }^{-1}$ ).

Experimental design: To identify the host suitability sandal during transit host (Intermediate host), the host species selected are Cynodon dactylon, Chrysopogon zizanioides, Vigna unguiculata, Tephrosia purpurea, Sesbania grandiflora, Vachellia nilotica, Albizia lebbeck and Casuarina junghuhniana. Totally nine treatments, viz., $\mathrm{T}_{1}$ : Sandal + Cynodon dactylon; $\mathrm{T}_{2}$ : Sandal + Chrysopogon zizanioides; $\mathrm{T}_{3}$ : Sandal + Vigna unguiculata; $\mathrm{T}_{4}$ : Sandal + Tephrosia purpurea; $\mathrm{T}_{5}$ : Sandal + Sesbania grandiflora; $\mathrm{T}_{6}$ : Sandal + Vachellia nilotica; $\mathrm{T}_{7}$ : Sandal + Albizia lebbeck; $\mathrm{T}_{8}$ : Sandal + Casuarina junghuhniana and $\mathrm{T}_{9}$ : Control (Sandal alone) with three replication in a randomized block design. The host suitability study of sandal during field establishment was initated with drip irrigation and irrigation schedule was once in every three days during summer/non rainy days for first six months and at later stages it was irrigated for twice/week with the discharge rate of $4.0 \mathrm{Ihr}^{-1}$ for one hour/day.

Biometric calculation: Biometric characteristics viz., height and basal diameter were measured during 6 months after planting (MAP), 9 MAP and 12 MAP. The height of the trees was measured from the ground level to the leading terminal tip using standard scale and was expressed in meter. Basal diameter is measured with the help of digital vernier caliper at the ground level and expressed in centimeters.

Chlorophyll content: The concentrations of chlorophyll 'a', chlorophyll 'b', total chlorophyll and chlorophyll a/b ratio were 
estimated by the method of Yoshida et al. (1976) and expressed as $\mathrm{mg} \mathrm{g}^{-1}$ f.wt. Fully matured young fresh leaf samples $(250 \mathrm{mg})$ were collected, washed in distilled water and then ground in $80 \%$ acetone using pestle and mortar. The homogenate solution was centrifuged at $500 \mathrm{rpm}$ for $10 \mathrm{~min}$. The supernatant was collected and the volume was made up to $25 \mathrm{ml}$ with $80 \%$ acetone. The optical density of the content was measured at 663 and $645 \mathrm{~nm}$ using double beam UV Spectrophotometer. The chlorophyll 'a', chlorophyll 'b' and total chlorophyll content were calculated.

Estimation of leaf photosynthesis and transpiration rate: Using a Portable Photosynthesis System (PPS, model LCpro + Photosynthesis System $\mathrm{CO}_{2}$ gas analyzer, UK), the net rate of photosynthesis rate and transpiration rate were estimated for one-year- sandal plantation with the different host between 09.00 am to $11.00 \mathrm{am}$ for three sunny days for effective results. The observed $\mathrm{CO}_{2}$ concentration during field experiment varied between $350 \mathrm{ppm}$ to $360 \mathrm{ppm}$ with the leaf temperature of $32.5^{\circ} \mathrm{C}$ on fully matured leaves (5-6 leaves from the bud).

Statistical analysis: Data were subjected for statistical analysis to evaluate the possible relationship between different parameters and to employ analysis of variance (Gomez and Gomez, 1984). The comparison between different host planted in sandal were assessed using ANOVA and the physiological analysis were carried out through SPSS.

\section{Results and Discussion}

Sandal plants showed a significant growth performance in terms of (height and basal diameter) in association with host species, when compared with Control (Sandal alone). This clearly indicated that the host-tree interaction in sandal had influenced the growth. Among the eight different host planted, the height (1.96) and basal diameter (4.39) $\mathrm{cm}$ were significantly greater in Sesbania grandiflora with during one-year-of growth (Table 1 and Figure 1). In a similar study Balasubramanian et al. (2018) stated that sandal growth with Alternanthera sessilis + Sesbania grandiflora recorded superior growth with height of $1.45 \mathrm{~m}$ during 8 months after planting. Sandal grown with leguminous host showed superior growth performance than sandal grown with non-leguminous host (Durairaj and Kamaraj, 2016).

The xylem tapping root Hemiparasite was grown superior during the association with nitrogen-fixing hosts (Lu et al., 2014; Press and Phoneix, 2005; Bell and Adams, 2011). On competing next to Sesbania grandiflora, Sandal showed good biometric growth in Albizia lebbeck and Casuarina junghuhniana with height of $1.77 \mathrm{~m}$ and $1.71 \mathrm{~m}$. The lowest growth performance (Height- 1.02 $\mathrm{m}$ and Basal diameter- $2.22 \mathrm{~cm}$ ) was observed in control (Sandal alone). In order to support the present investigation, Durairaj and Kamaraj (2016) exhibited that growth increment was observed in sandal grown with host than sandal without host. Host-sandal interaction is related to uptake, translocation of various mineral nutrients and photosynthesis efficiency (Ananthapadmanabha et al., 1984; Rangaswamy et al., 1986; Brand 2002; Lu et al., 2014; Rocha et al., 2014; Balasubramanian et al., 2018). In the present study, the maximum chlorophyll content was recorded in Sandal + Sesbania grandiflora, followed by Sandal + Casuarina junghuhniana (Table 2). Eventhough sandal have functional chloroplast to perform photosynthesis, the functional haustoria duly played an important role in water uptake and physiological action of the parasite (Pate,

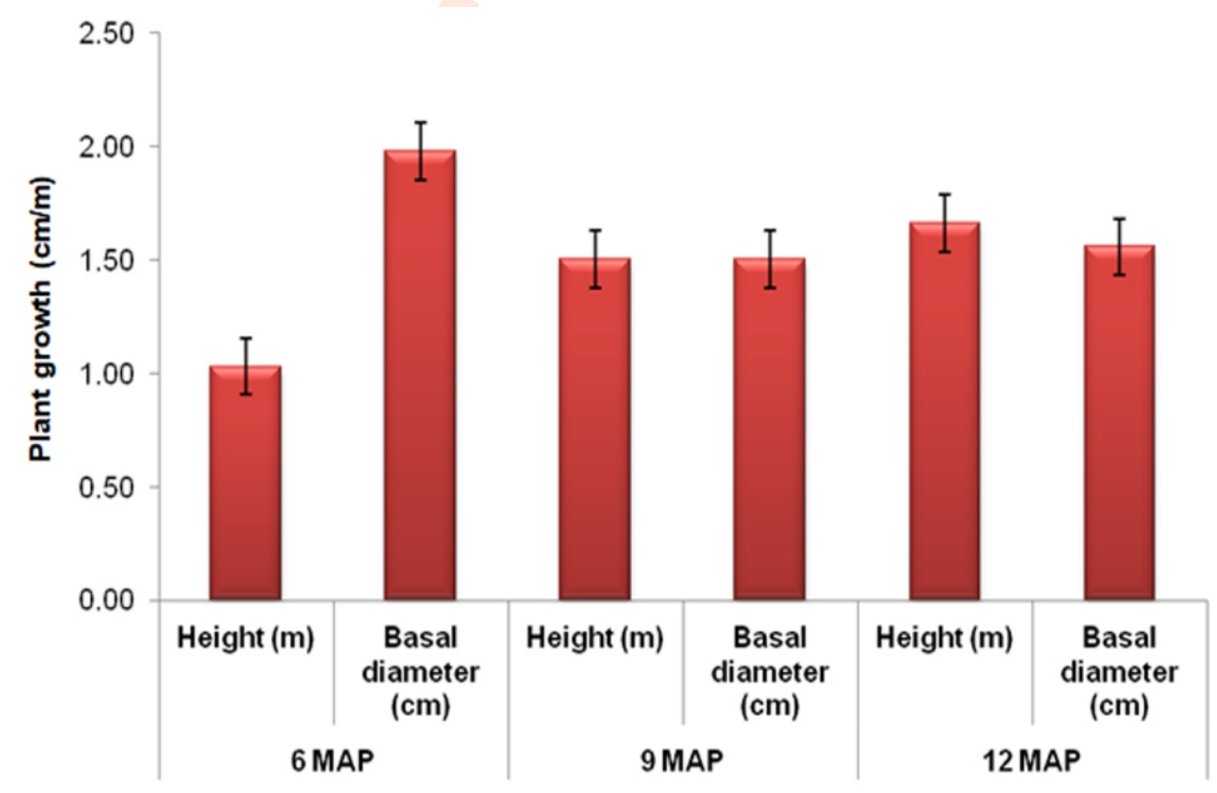

Fig. 1: Influence of different host association on growth performance of sandal (Santalum album) at different stages. 
Table 1: Host-specific interactions on height and basal diameter of sandal

\begin{tabular}{llllllll}
\hline & & \multicolumn{2}{c}{ 6 MAP } & \multicolumn{2}{c}{9 MAP } & \multicolumn{2}{c}{ 12 MAP } \\
\cline { 3 - 8 } & Treatments & $\begin{array}{l}\text { Height } \\
(\mathbf{m})\end{array}$ & $\begin{array}{l}\text { Basal diameter } \\
(\mathbf{c m})\end{array}$ & $\begin{array}{l}\text { Height } \\
(\mathbf{m})\end{array}$ & $\begin{array}{l}\text { Basal } \\
\text { diameter }(\mathbf{c m})\end{array}$ & $\begin{array}{l}\text { Height } \\
(\mathrm{m})\end{array}$ & $\begin{array}{l}\text { Basal } \\
\text { diameter }(\mathbf{c m})\end{array}$ \\
\hline $\mathrm{T}_{1}$ & Sandal + Cynodon dactylon & 0.99 & 1.87 & 1.21 & 2.24 & 1.58 & 2.96 \\
$\mathrm{~T}_{2}$ & Sandal + Chrysopogon zizanioides & 1.04 & 2.05 & 1.29 & 2.78 & 1.66 & 2.46 \\
$\mathrm{~T}_{3}$ & Sandal + Vigna unguiculata & 1.03 & 2.23 & 1.30 & 2.86 & 1.65 & 1.98 \\
$\mathrm{~T}_{4}$ & Sandal + Tephrosia purpurea & 0.98 & 1.90 & 1.19 & 2.55 & 1.46 & 2.16 \\
$\mathrm{~T}_{5}$ & Sandal + Sesbania grandiflora & 1.21 & 2.41 & 1.45 & 3.25 & 1.96 & 4.39 \\
$\mathrm{~T}_{6}$ & Sandal + Vachellia nilotica & 1.08 & 1.99 & 1.31 & 2.63 & 1.65 & 3.62 \\
$\mathrm{~T}_{7}$ & Sandal + Albizia lebbeck & 1.18 & 2.27 & 1.34 & 3.01 & 1.77 & 3.29 \\
$\mathrm{~T}_{8}$ & Sandal + Casuarina junghuhniana & 1.07 & 1.98 & 1.17 & 2.76 & 1.71 & 3.89 \\
$\mathrm{~T}_{9}$ & Control & 0.69 & 1.12 & 0.91 & 1.99 & 1.02 & 2.22 \\
& S.Ed & 0.031 & 0.070 & 0.046 & 0.118 & 0.070 & 0.162 \\
& CD (0.05) & 0.065 & 0.147 & 0.096 & 0.248 & 0.148 & 0.341 \\
\hline
\end{tabular}

Table 2: Influence of different host association on chlorophyll content $\left(\mathrm{mg} \mathrm{g}^{-1}\right)$ of one-year-old sandal

\begin{tabular}{llllll}
\hline & Treatments & Chlorophyll 'a' & Chlorophyll 'b' & Total chlorophyll & Chlorophyll a/b ratio \\
\hline $\mathrm{T}_{1}$ & Sandal + Cynodon dactylon & 0.548 & 0.328 & 0.876 & 1.671 \\
$\mathrm{~T}_{2}$ & Sandal + Chrysopogon zizanioides & 0.606 & 0.291 & 0.897 & 2.082 \\
$\mathrm{~T}_{3}$ & Sandal + Vigna unguiculata & 0.698 & 0.363 & 1.061 & 1.923 \\
$\mathrm{~T}_{4}$ & Sandal + Tephrosia purpurea & 0.611 & 0.289 & 0.900 & 2.114 \\
$\mathrm{~T}_{5}$ & Sandal + Sesbania grandiflora & 0.790 & 0.470 & 1.260 & 1.681 \\
$\mathrm{~T}_{6}$ & Sandal + Vachellia nilotica & 0.601 & 0.300 & 0.901 & 2.003 \\
$\mathrm{~T}_{7}$ & Sandal + Albizia lebbeck & 0.721 & 0.317 & 1.038 & 2.274 \\
$\mathrm{~T}_{8}$ & Sandal + Casuarina junghuhniana & 0.700 & 0.398 & 1.098 & 1.759 \\
$\mathrm{~T}_{9}$ & Control & 0.500 & 0.195 & 0.695 & 2.564 \\
& $\mathrm{~S} . \mathrm{Ed}$ & 0.026 & 0.013 & 0.047 & 0.099 \\
& $\mathrm{CD}(0.05)$ & 0.056 & 0.027 & 0.099 & 0.209 \\
\hline
\end{tabular}

Table 3: Influence of different host association on photosynthesis rate and transpiration rate on one-year-old sandal

\begin{tabular}{llll}
\hline & Treatments & $\begin{array}{l}\text { Photosynthesis rate } \\
\left(\boldsymbol{\mu} \text { mol. } \mathbf{~ m}^{-2} \mathbf{s}^{-1}\right)\end{array}$ & $\begin{array}{l}\text { Transpiration rate } \\
\left(\mathbf{m ~ m o l}^{-2} \mathbf{~ m}^{-1}\right)\end{array}$ \\
\hline $\mathrm{T}_{1}$ & Sandal + Cynodon dactylon & 12.75 & 4.67 \\
$\mathrm{~T}_{2}$ & Sandal + Chrysopogon zizanioides & 13.23 & 5.02 \\
$\mathrm{~T}_{3}$ & Sandal + Vigna unguiculata & 12.71 & 4.22 \\
$\mathrm{~T}_{4}$ & Sandal + Tephrosia purpurea & 8.76 & 3.87 \\
$\mathrm{~T}_{5}$ & Sandal + Sesbania grandiflora & 18.42 & 5.56 \\
$\mathrm{~T}_{6}$ & Sandal + Vachellia nilotica & 10.11 & 3.90 \\
$\mathrm{~T}_{7}$ & Sandal + Albizia lebbeck & 15.55 & 5.33 \\
$\mathrm{~T}_{8}$ & Sandal + Casuarina junghuhniana & 15.49 & 5.08 \\
$\mathrm{~T}_{9}$ & Control & 7.56 & 3.73 \\
& $\mathrm{~S} . \mathrm{Ed}$ & 0.586 & 0.232 \\
& $\mathrm{CD}(0.05)$ & 1.233 & 0.487
\end{tabular}

$\mathrm{T}_{1}:$ Sandal + Cynodon dactylon; $\mathrm{T}_{2}:$ Sandal + Chrysopogon zizanioides; $\mathrm{T}_{3}:$ Sandal + Vigna unguiculata; $\mathrm{T}_{4}:$ Sandal + Tephrosia purpurea; $\mathrm{T}_{5}:$ Sandal + Sesbania grandiflora; $\mathrm{T}_{6}:$ Sandal + Vachellia nilotica; $\mathrm{T}_{7}:$ Sandal + Albizia lebbeck; $\mathrm{T}_{8}:$ Sandal + Casuarina junghuhniana and $\mathrm{T}_{9}:$ Control 
2001; Bell and Adams, 2011; Cameron and Seel, 2007).

Sandal plants grown with the host showed significant increase in rate of photosynthesis and transpiration than without host, especially sandal with leguminous host showed an increasing trend. An interesting finding from this study was that the Sandal grown with Sesbania grandiflora recorded highest photosynthesis rate of $18.42 \mu \mathrm{mol} . \mathrm{m}^{-2} \mathrm{~s}^{-1}$ and transpiration rate of $5.56 \mathrm{~m} \mathrm{~mol} . \mathrm{m}^{-2} \mathrm{~s}^{-1}$ followed by Sandal + Albizia lebbeck and Sandal + Casuarina junghuhniana with photosynthetic rate of $15.55 \mu \mathrm{mol} . \mathrm{m}^{-2} \mathrm{~s}^{-1}$ and $15.49 \mu \mathrm{mol} . \mathrm{m}^{-2} \mathrm{~s}^{-1}$. The photosynthetic rate of leguminous tree species Albizia lebbeck is on par with the non-leguminous tree species Casuarina junghuhniana (Table 3). Lu et al. (2014) found that improved rates of photosynthesis in Santalum album, when grown in association with $\mathrm{N}_{2}$ fixing Acacia confusa and Dalbergia odorifera provide circumstantial evidence that Santalum album has a lower dependence on such hosts for carbon compared with non nitrogen fixing Bischofia polycarpa and Dracontomelon duperreranum.

In the present study, sandal with host showed superior photosynthetic rate (carbon assimilation rate) than sandal grown without host, which is in on par with the study conducted by Rocha et al. (2014). The photosynthesis rate of 7.56 and transpiration rate of 3.73 was recorded in Sandal without host in the present study. A significant difference was observed in rate of photosynthesis between sandal with host and without host (Tennakoon et al., 1997). Jiang et al. (2003) and Taylor et al. (1996) indicated that Santalum album clearly appears to optimize root xylem sap extraction from its hosts in the same way as obligate hemiparasite Striga hermonthica and facultative hemiparasite Rhinanthus minor by having higher transpiration rates and lower Water Use Efficiency (WUE) values than in the host.

In conclusion, sandal along with Sesbania grandiflora showed better growth and physiological performance at early stage as transit host. Sesbania grandiflora performed better as transit host to sandal upto 2 years by inducing good root proliferation and excellent haustoria association, which help in water translocation and uptake of various mineral nutrients. The complex interaction between parasite and host (Sesbania grandiflora) during early growth stage of Santalum album, boosted the growth during initial stage of plantation.

\section{Acknowledgments}

The authors are thankful to Vice Chancellor, Tamil Nadu Agricultural University, Coimbatore and Dean, Forest College and Research Institute, Mettupalayam for providding necessary support in establishing the sandal plantation.

\section{Add-on Information}

Authors' contribution: A. Balasubramanian: Field preparation as per different sandal treatments and corrected the paper; C.N.
Hari Prasath: Collected biometric data and ecophysiological data. Formulated the data; S. Radhakrishnan: Statistical analysis of data; M. Sivaprakash: Collection of literature related to sandal.

Research content: The research content of manuscript is original and has not been published elsewhere.

Ethical approval: NotApplicable

Conflict of interest: The authors declare that there is no conflict of interest.

\section{Data from other sources: NotApplicable}

Consent to publish: All authors agree to publish the paper in Journal of Environmental Biology.

\section{References}

Ananthapadmanabha, H.S., C.R. Rangaswamy, C.R. Sarma, H.C. Nagaveni, S.H. Jain, K.R. Venkatesan and H.P. Krishnappa: Host requirement of sandal (Santalum album L.). Indian Forester., 110, 264-268 (1984).

Baboo, B., R. Sagar, S.S. Bargali and H. Verma: Tree species composition, regeneration and diversity within the protected area of Indian dry tropical forest. Tropi. Ecolo., 58, 409-423 (2017).

Balasubramanian, A., C.N. Hari Prasath, S. Manivasakan and S. Radhakrishnan: Influence of host on the early growth performance of sandal tree (Santalum album) grown in farm settings. Int. J. Ecol. Environ. Sci., 44, 369-372 (2018).

Bargali, K., Vijyeta Manral, Kirtika Padalia, S.S. Bargali and V.P. Upadhyay: Effect of vegetation type and season on microbial biomass carbon in Central Himalayan forest soils. India. Catena, 171, 125-135(2018).

Bargali, S.S., K. Padalia and K. Bargali: Effects of tree fostering on soil health and microbial biomass under different land use systems in central Himalaya. Land Degrad. Develop., 30, 1984-1998 (2019).

Bell, T.L. and M.A. Adams: Attack on all fronts: Functional relationships between aerial and root parasitic plants and their woody hosts and consequences for ecosystems. Tree Physiol., 31, 3-15 (2011).

Brand, J.E.: Review of influence of Acacia species on establishment of sandalwood (Santalum spicatum) in Western Australia. Conserv. Sci. WesternAustralia., 4, 125-129 (2002).

Cameron, D.D. and W.E. Seel: Functional anatomy of haustoria formed by Rhinanthus minor: linking evidence from histology and isotope tracing. New Phytol., 174, 412-419 (2007)

Costanza, R., R.D'arge, R.D. Groot, S. Farber, M. Grasso, B. Hannon, K. Limburg, S. Naeem, R.V. O'neill, J. Paruelo, R.G. Raskin, P. Sutton and M.V.D. Belt: The value of the world's ecosystem services and natural capital. Nature, 387, 253-260 (1997).

Dhanya, B., V. Syam and P. Seema: Sandal (Santalum album L.) con?servation in Southern India: A review of policies and their impacts. J. Trop. Agric., 48, 1-10 (2010).

Durairaj, P. and M. Kamaraj: Host species dependent vegetative growth parameters of Santalum album L. Int. J. Biosci. Nano. Sci., 3, 90-93 (2016).

Ehrhart, Y. and J.E.D. Fox: State of knowledge regarding cultivation of sandalwood. In: Sandalwood seed nursery and plantation technology. Field Document No. 8. RAS/92/361. FAO, Suva, pp. 275-291 (1995). 
FSI: Chapter 2: Forest cover. In: State of Forest Report. Ministry of Environment and Forests, Government of India, pp. 11-33 (2011).

Gairola, S., G. Ravi Kumar and P. Aggarwal: Status of production and marketing of sandalwood (Santalum album L.). In: Conservation, Improvement, Cultivation and Management of Sandal (Santalum album L.). (Eds.: S. Gairola, T.S. Rathore, G. Joshi, A.N. Arun Kumar and P.K. Aggarwal). IWST, Bangalore. pp. 1-8 (2008).

Gomez, K.A. and A.R. Gomez: Statistical Procedures for Agricultural Research, $2^{\text {nd }}$ Edn., John Wiley and Sons, New York, 680 pages (1984).

Htun, N.Z., N. Mizoue and S. Yoshida: Tree species composition and diversity at different levels of disturbance in Popa Mountain Park, Myanmar. Biotropica, 43, 597-603 (2011).

Hughes, J.B., G.C. Daily and P.R. Ehrlich: Population diversity: Its extent and extinction. Science, 278, 689-692 (1997).

Jiang, F., W.D. Jeschke and W. Hartung: Water flows in the parasitic association Rhinanthus minor/Hordeum vulgare. J. Exp. Bot., 54, 1985-1993 (2003)

Kim, T. H., H. Ito, K. Hayashi, T. Hasegawa, T. Machiguchi and T. Yoshida: Aromatic constituents from the heartwood of Santalum album L.. Chem. Pharm. Bull., 53, 641-644 (2005)

Kittur. B., S.L. Swamy, S.S. Bargali and M.K. Jhariya: Wildland fires and moist deciduous forests of chhattisgarh, India: Divergent component assessment. J. Fore. Res., 25, 857-866 (2014).

Lu J.K., D.P. Xu, L.H. Kang and X.H. He: Host-species-dependent physiological characteristics of hemiparasite Santalum album in association with N2-fixing and non-N2-fixing hosts native to southern China. Tree Physiology., 34, 1006-1017 (2014).

Manral, V., K. Bargali, S.S. Bargali and C. Shahi: Changes in soil biochemical properties following replacement of Banj oak forest with Chir pine in Central Himalaya, India. Ecol. Proc., 9, 30 (2020).

Marshall, J., T. Dawson and J. Ehleringer: Integrated nitrogen, carbon, and water relations of a xylem-tapping mistletoe following nitrogen fertilization of the host. Oecologia, 100, 430-438 (1994)

Maurya N.R., K. Bargali and S.S. Bargali: Effect of Coriaria nepalensis Wall. Colonization in a mixed conifer forest of Indian Central Himalaya. J. Fore. Res., 30, 305-317 (2019).

Myers, N.: Mass extinctions: what can the past tell us about the present and the future? Palaeogeography, Palaeoclimatology, Palaeoecology (Global and Planetary Change section), 82, 175-85(1990)

Pandey, R., Vibhuti, H. Karki, P. Awasthi, K. Bargali and S.S. Bargali:
Effect of wildfire on herbaceous vegetation in cypress mixed oak forest of Nainital, Kumaun Himalaya, India. Curr. Trends Fore. Res., 2, 1-17 (2018).

Pate, J.S.: Haustoria in action: case studies of nitrogen acqui $า$ sition by woody xylem-tapping hemiparasites from their hosts. Protoplasma, 215, 204-217(2001)

Pimm, S.L. and P. Raven: Biodiversity: Extinction by numbers. Nature, 403, 843-845 (2000)

Press, M.C. and G.K. Phoenix: Impacts of parasitic plants on natural communities. New Phytol., 166, 737-751(2005).

Radomiljac, A.M., J.A. McComb, J.S. Pate and K.U. Tennakoon: Xylem transfer of organic solutes in Santalum album L. (Indian sandalwood) in association with legume and non-legume hosts. Ann. Bot., 82, 675-682 (1998).

Rangaswamy, C.R., S.H. Jain and K. Parthasarathi: Soil properties of some sandal bearing areas. Van Vigyan, 24, 61-68 (1986).

Rocha, D., P.K. Ashokan, A.V. Santhoshkumar, E.V. Anoop and P. Sureshkumar: Influence of host plant on the physiological attributes of field-grown sandal tree (Santalum album). J. Tropi. Fore. Sci., 26, 166-172 (2014)

Surendran, C., K.L. Parthiban, C. Bhuvaneshwaran and M. Murugesh: Silvicultural strategies for augmentation of sandal regeneration. In Sandal and its Products. (Eds.: A.M. Radomiljac, H.S. Ananthapadmanabha, R.M. Welbourn and K. Satyanarayana Rao). ACIAR Proceedings. No.84. ACIAR, Canberra, Australia, pp. 69-73 (1998).

Taylor, A., J. Martin and W.E. Seel: Physiology of the parasitic asso 7 ciation between maize and witchweed (Striga hermonthica): is ABAinvolved?. J. Exp. Bot., 47,1057-1065 (1996).

Tennakoon, K.U., J.S. Pate and D. Arthur: Ecophysiological aspects of the woody root hemiparasite Santalum acuminatum (R. Br.) A. DC and its common hosts in south Western Australia. Ann. Bot., 80, 245-256 (1997).

Wilson, E.O.: The current state of biological diversity. In: Biodiversity. (Eds.: E.O. Wilson and F.M. Peter). National Academy Press, Washington, DC, USA, pp. 3-18 (1988).

Yang, X., X. Zhang, J.A. Teixeira da Silva, K. Liang, R. Deng and G. Ma: Ontogenesis of the collapsed layer during haustorium development in the root hemi-parasite Santalum album Linn. Plant Biol., 16, 282-290 (2014).

Yoshida, S., D. Forna, J. Cock and K. Gomez: Determination of chlorophyll in plant tissues. In laboratory manual for physiological studies of Rice. The International Rice Research Institute. Los Banos, Laguna, Philippines, pp. 43-45 (1976) 